\title{
プラズマアクチュエータを用いた翼前縁はく離の制御における 位置および個数の影響*
}

\author{
椿 野大 輔*1, 田中義 輝*1, 藤 井孝藏*2 \\ Effects of Plasma Actuator Layouts on \\ a Flow Separation Control over a Wing
}

Daisuke TSUBAKINO*3, Yoshiteru TANAKA and Kozo FUJII

\begin{abstract}
${ }^{* 3}$ Department of Aeronautics and Astronautics, Graduate School of Engineering, The University of Tokyo, 3-1-1 Yoshinodai, Sagamihara-shi, Kanagawa, 229-8510 Japan
\end{abstract}

\begin{abstract}
Effective location of plasma actuators for a flow separation control over a NACA 0012 airfoil is investigated by computational simulations. Single plasma actuator is located at $5 \%, 10 \%$ or $20 \%$ chord from the leading edge. The results indicate that the actuator located near the separation has a better capability to control flow separations. Separation is once avoided when a single actuator is located near the separation, another separation occurs from the trailing edge. This motivates to use multiple actuators and the separations are carried out for two actuators. The result shows the possibility that appropriate layouts of actuators can achieve high control performance with relatively low input voltage.
\end{abstract}

Key Words: Flow Control, Separation, Airfoil

\section{1. は じめに}

流体現象に対する制御技術は，壁面抵抗の軽減や空 力騒音低減など, 構造物の特性向上という工学的要求 から，多くの研究がなされており，いくつかの技術が 実用化されている，例えば航空宇宙分野では，翼の高 揚力化を目的としたボルテクスジェネレータや，フラ ップなどが挙げられる。これらの技術は, 基本的に受 動的かつ静的に行われるものが多く, 構造的な要因か ら応答性が高くないものが多い. しかしながら，実際 に工学的に問題となるような流れ場の多くは, 非定常 的な現象の変化を伴っており, 各瞬間の流れ場に応じ て瞬間に対応するような, 動的かつ能動的な流れ制御 技術が有効ではないかと考えられる.

近年，流れのはく離や乱流現象を中心として動的制 御技術が研究され始めており, 実際に多くの制御デバ イスが考案されている(1). そのような動的制御技術の 一つにプラズマアクチュエータがある。これは図 1 に

* 原稿受付 2006 年 7 月 5 日.

*1 東京大学大学院工学系研究科( ( 229-8510 相模原市由野台 3-1-1 宇宙科学研究本部).

*2 正員, フェロー, 宇宙航空研究開発機構宇宙科学研究本部 (覀229-8510 相模原市由野台 3-1-1).

E-mail : tsubakino@flab.eng.isas.jaxa.jp
示されるように, 2 枚の電極が絶縁体を挟み, 交流電 圧が加えられるような, 非常に簡単な構造をしてい る. 入力された交流電圧は電極間にバリア放電を生じ させ,アクチュエータ表面の大気を局所的にプラズマ 状態にする，それらが入力電圧による電場と生じた電 荷がつくる電場によって加速させられることで, 大気 中の局所的な領域に露出電極から被覆電極へ向かつ て, 流れが誘起される.この現象は, 電磁気現象と電 離・解離といった化学反応からなり, 流体現象に比べ て非常に短い時間スケールで生じている. そのため, 従来の機械系の制御装置に比べて非常に高い応答性が 期待できる. また, 入力電圧は数 $\mathrm{kV}$ と高いが, 生じ る電流は数十 $\mathrm{mA}$ と低いため, 消費電力は数 $\mathrm{W}$ と小 さい値となる，これは，実用上非常によい性質の一つ である。

$$
\text { プラズマアクチュエータに関して, 現在さまざまな }
$$

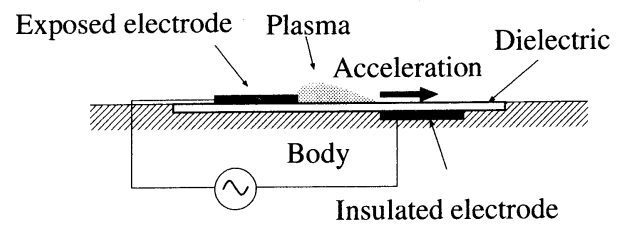

Fig. 1 Configuraion of plasma actuator 
研究が進んでおり, 多くの応用例が報告されてい る(2) (9). その応用分野は広く, 壁面の乱流抵抗の軽 減(10)やタービン翼列のすきま流れへの適用(3), ジェッ トや航空機のランディングギヤから生じる空力騷音の 軽減への適用 ${ }^{(1)(12)}$ など多岐に及ぶ。高迎え角飛行時 の翼面上流れのはく離の制御はその応用例の一つであ り，実際に翼の失速特性を大きく向上できることが示 されている(2).この制御技術は, アクチュエータの装 置の簡素さもあり, 従来の航空機だけでなく, 近年注 目されている超小形無人航空機 $(\mathrm{MAV})$ や, 火星環境 を飛行しながら探査する, 火星航空機に対してもその 有効性が期待される.

これまでのプラズマアクチュエータを用いた翼面上 のはく離制御に対する研究は, 単数のアクチュエータ をある特定箇所に配置して，その効果を見るものが多 い. 確かに有効性は示されるが, 実用を考えれば, ア クチュエータの効率的な使用法を考えることが望まし い.アクチュエータにより誘起される速度は, 入力電 圧に比例することが知られているが, 入力電圧は搭載 する航空機の構造やその他の機器により制限されるの が普通であり, また, ある入力電圧以降は誘起速度は 漸近的になることが示されているからである(7). 効率 的な使用の観点では, アクチュエータの性能向上のた め, 電極などの構造を最適化させる研究や(7), 入力電 圧波形を操作し, 性能を向上させる研究もある(2).し かし, 翼面上のアクチュエータの配置に関する影響の 考察や, 複数配置したときの効果を見せたものはな い.

そこで, 本研究では, 低レイノルズ環境 $\left(R e \sim 10^{5}\right)$ で前縁から大規模なはく離を起こしやすい, NACA 0012 翼の翼面上のはく離制御に対して, 位置 に関する定性的な影響の考察を行う。そのため, はく 離点が存在すると考えられる翼前緑付近のうち, 前緑 より $5,10 \%$ 抢よび $20 \%$ 翼弦位置に単数のアクチュ工 ー夕を配置したときのそれぞれの効果を二次元数值シ ミュレーションを用いて考察する．また，消費電圧の 低減を目指し, 複数のアクチュエータを同時に用いた ときの効果を調べるために, 前縁より $5 \%$ と $10 \%$ 翼弦 位置両方に配置した場合の考察も行う.

\section{2. 数值計算法}

$2 \cdot 1$ 支配方程式支配方程式には, 通常の二次 元 Navier-Stokes 方程式に,アクチュエータの効果 を考慮した方程式を用いた。をれらは，質量保存則， 運動量保存則, そしてエネルギー保存則からなり,一 様流条件で無次元化を行った形で次のように表され
る.

$$
\begin{aligned}
& \frac{\partial \rho}{\partial t}+\frac{\partial \rho u_{k}}{\partial x_{k}}=0 \\
& \frac{\partial \rho u_{i}}{\partial t}+\frac{\partial\left(\rho u_{i} u_{k}+p \delta_{i k}\right)}{\partial x_{k}}=\frac{1}{R e} \frac{\partial \tau_{i k}}{\partial x_{k}}+D_{c} q_{c} E_{i}
\end{aligned}
$$

$$
\begin{aligned}
& \frac{\partial e}{\partial t}+\frac{\partial\left\{(e+p) u_{k}\right\}}{\partial x_{k}}=\frac{1}{\operatorname{Re}} \frac{\partial u_{l} \tau_{k l}}{\partial x_{k}} \\
& +\frac{1}{(\gamma-1) \operatorname{PrReM} M_{\infty}^{2}} \frac{\partial q_{k}}{\partial x_{k}}+D_{c} q_{c} u_{k} E_{k}
\end{aligned}
$$

ここで, $u_{i}, q_{i}, \rho, p, e, \tau_{i j}, \delta_{i j}$ および $t$ は, それぞれ速 度ベクトル, 熱流束ベクトル, 密度, 圧力, 単位体積あ たりの全エネルギー, 応力テンソル, クロネッカーの デル夕拉よび時間である。また, 絽返される添字は, 和の規約を用いており，2 までの和をとることとする. 式中の 3 の基本的な無次元数 $R e, M_{\infty}, \operatorname{Pr}$ は, それぞ れレイノルズ数, 一様流マッ八数, プラントル数であ り, 次式で表される.

$$
R e=\frac{\rho_{\infty} u_{\infty} L_{\text {chord }}}{\mu_{\infty}}, \quad M_{\infty}=\frac{u_{\infty}}{a_{\infty}}, \quad \operatorname{Pr}=\frac{\mu_{\infty} C_{p}}{k_{\infty}}
$$

ここで, $\mu, L_{\text {chord }}, a, c_{p}$ そして $k$ は, それぞれ粘性係 数, 翼弦長, 音速, 定圧比熱であり, 添字字“侄” 一様流状態を表している.

アクチュエータの作り出す流れは, 局時的なもので あり, はく離や失速の構造は, 非定常性が大きくかか わることが示されている(13). しかしながら, 目的で述 べたように, 本研究で注目しているのは, 失速の予測 やはく離構造の解明ではなく, はく離抑制の傾向を把 握することである.よって, 定性的な議論に主眼をお いているので, RANS の二次元シミュレーションで 構わないと考え, 乱流モデルとして Baldwin-Lomax モデルを用いた(14).

式 (1),（3）の右辺の最終項がアクチュエータの影 響を表す項であり, $q_{c}$ は, プラズマの電荷密度, $E_{i}$ は，電場ベクトルをそれぞれ表している，D $D_{c}$ は電磁 力項の無次元数である.これらについては, $2 \cdot 3$ 節で 扱う。

$2 \cdot 2$ 空間および時間の離散化 空間の離散化に は, AUSM 系のスキームであるSHUS ${ }^{(15)}$ MUSCL 法(16)により高次精度化したものを用いた。また，時 間積分は, 使用計算機の特性を考慮し FF-SGS ${ }^{(17)}$ の 考えを用いて，陰解法である LU-ADI ${ }^{(18)}$ の各方向に スペクトル半径で風上化を施した ADI-SGSを用い た。

2・3 アクチュエータの計算モデルプラズマア クチュエータで生じる現象は, 電子の反応がかかわる 


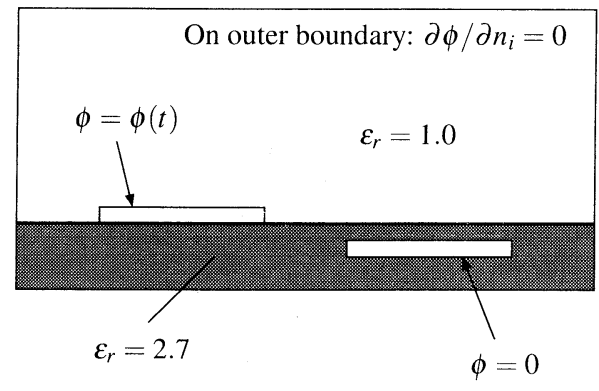

Fig. 2 Boundary conditions for Eq. ( 5 )

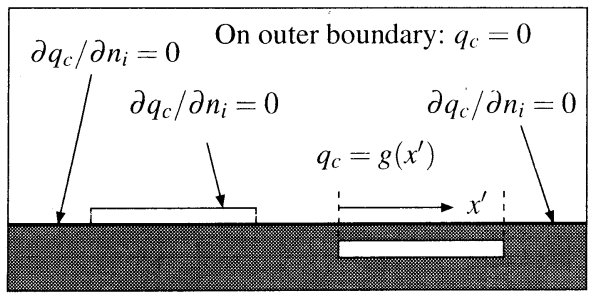

Fig. 3 Boundary conditions for Eq. (6)

ような, 非常にミクロで短い時間スケールの現象であ るので, 直接これらの効果を計算に取り込むのは困難 である.電離・解離反応も考慮して計算を行った研究 もあるが(19)(20), 現象をマクロにとらえるような数值 計算モデルが，実用上有用なデータを与えてくれる。 現在さまざまな計算モデルが考案されているが(5)(8)(21), 本研究では, Suzenらによって提案されたモデルを用 いる(8).

このモデルでは, 電荷密度分布 $q_{c}$ および電場べク トル分布 $E_{i}$ を次の方程式の解として与える.

$$
\begin{aligned}
& \frac{\partial E_{k}}{\partial x_{k}}=\frac{\partial}{\partial x_{k}}\left(\varepsilon_{r} \frac{\partial \phi}{\partial x_{k}}\right)=0, \\
& \frac{\partial}{\partial x_{k}}\left(\varepsilon_{r} \frac{\partial q_{c}}{\partial x_{k}}\right)=\frac{q_{c}}{\lambda_{d}^{2}}, \cdots \cdots \cdots . .
\end{aligned}
$$

ここで, $\varepsilon_{r}$ は物体の比誘電率, $\phi$ はスカラポテンシャ ルであり， $\lambda_{d}$ はデバイ長である. 計算では, $\lambda_{d}=$ 0.001 とした. 式（５）は，図 2 の堺界条件のもと, 式 （6）は，図 3 の境界条件のもとで解く,ただし, 図 2 中の $\phi(t)$ は, 入力電圧であり, 次式で与えられるとす る.

$$
\phi(t)=\phi_{\max } f(t)
$$

また, 図 3 中で, 被覆電極上の誘電体表面の境界条件 $g(x)$ は,

$$
g\left(x^{\prime}\right)=q_{c, \max } G\left(x^{\prime}\right) f(t)
$$

であり, $G(x)$ は, Suzen らに基づき, 正規分布で与え ている.

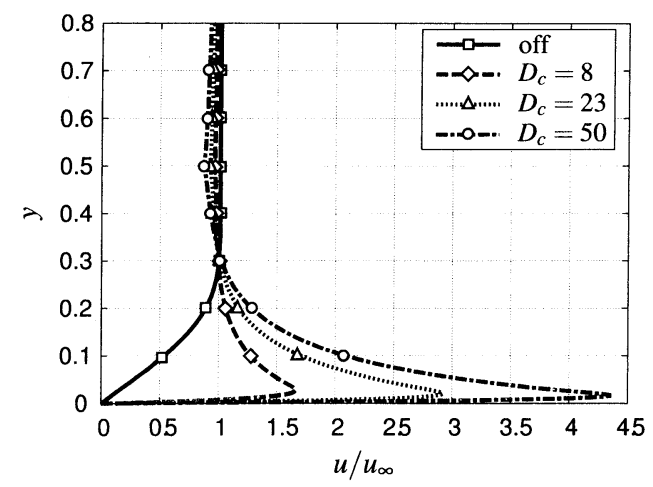

Fig. $4 u$-velocity profile on the flat plate with and without actuator

$$
G\left(x^{\prime}\right)=e^{-x^{\prime 2} / 2 \sigma^{2}}
$$

ただし， $\sigma=0.003$ として計算を行った。このように 求めた， $q_{c}, E_{i}$ を支配方程式に代入することで，アク チュエータの効果を取り入れている.さらに詳しい議 論は, 文献を参照していただきたい(8).

次に, 支配方程式 (2), (3) 中の電磁力項の無次元 数 $D_{c}$ の扱いについて述べる. $D_{c}$ は次のように表さ れる。

$$
D_{c}=\frac{q_{c, \text { ref }} E_{\mathrm{ref}} L_{\mathrm{chord}}}{\rho_{\infty} \mathcal{U}_{\infty}^{2}}=\frac{q_{c, \mathrm{ref}} \phi_{\mathrm{ref}}}{\rho_{\infty} \mathcal{U}_{\infty}^{2}},
$$

つまり, 流れの運動エネルギーと電磁力からのエネル ギーの比である. 式中の $\phi_{\mathrm{ref}}, q_{c, \mathrm{ref}}$ は, 電圧, 電荷の 参照量であるが, 本計算ではこれらの值として, 式 (7)，（8）の $\phi_{\max }, q_{c, \max }$ を用いる。この決め方から わかるように, $D_{c}$ を変化させることは, 入力電圧を変 化させることに対応する.よって, 以下 $D_{c}$ の值を, 電圧を表す指標とする，また，無風状態の実験では一 様流が存在しないことと, $q_{c, \max }$ の直接的な計側が困 難であるため定義することが難しいことから， $D_{c}$ の 值を定めることが難しい.そこで, 誘起速度から $D_{c}$ 值を見積ると, 主流と同程度の速度を誘起する $D_{c}$ は, 8 程度となる.

次にモデルの検証のために, マッハ数 $M_{\infty}=0.2$ の 一様流平板に対し行った計算結果を示す. 図 4 に, ア クチュエータ直後(約 $R_{x}=4.4 \times 10^{3}$ 位置)での速度 プロファイルを示す， Uは流速の平板に沿う方向成 分, $y$ は平板に垂直な方向の位置, $u_{\infty}$ は一様流速をそ れぞれ表す。アクチュエータが off のときは，よく知 られているブラシウス解の速度分布となっている。こ の速度分布にアクチュエータによる流れの加速の効果 が加わることで, 多くの実験や計算で示されているよ うに, 本解析でも境界層下部に速度が誘起される現象 


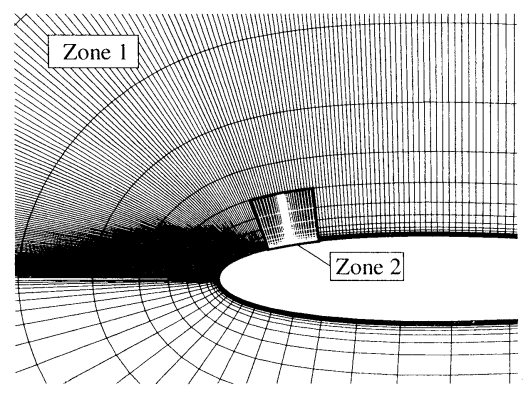

Fig. 5 Computational grid

を再現できている.また $D_{c}$ (入力電圧)を増やすにつ れ, 誘起速度が増加する傾向があることも見て取れ る. 以上より, 本解析で用いているプラズマアクチュ エータの数值計算モデルは, 実際のアクチュエータが 引き起こす流れ現象を定性的に再現できているといえ る.

$2 \cdot 4$ 計算格子 前縁より $10 \%$ 翼弦位置に配置し たときの計算格子を, 図 5 に示す.計算ではアクチュ エータの配置の変化を効率的に行うため, 重合格子法 を用い, 翼部をZone 1, アクチュエータ部をZone 2 とした．他の配置条件も同様に取扱った，翼格子に関 しては, 揚力係数を対象にした格子収束性の確認を行 っている.

\section{3. 数值計算条件}

本研究では, 火星大気中を飛行する航空機形の探査 機への応用を考えているため, 一様流条件は火星大気 を低速で飛行するという条件を与えている。つまり， $\operatorname{Re}=1.0 \times 10^{5}, M_{\infty}=0.1, \operatorname{Pr}=0.72$ とした.また， 火星大気を模擬し比熱比を $\gamma=1.34$ としているが， $\gamma$ の影響はほとんどない.

はく離は非定常現象であるため, 計算結果はすべて 時間平均を行っている. また, 使用モデルにおいて入 力周波数の影響がほとんど現れないことが確認された ため, 入力電圧はすべて実効値で一定值を与えてい る.

\section{4. 結果および考察}

$4 \cdot 1$ 単数のアクチュエータを用いた場合 単数 のアクチュエータを翼上面の前縁より $5,10 \%$ おび 20\%翼弦位置に配置した結果を示す。まず, 図 6 にア クチュエータを使用していない場合と, それぞれの位 置に配置し $D_{c}=50$ で使用した場合の揚力係数 $C_{L}$ の 迎え角変化を示す。アクチュエータ off の状態を見る と, 迎え角が $15^{\circ}$ を超えるころには失速していること

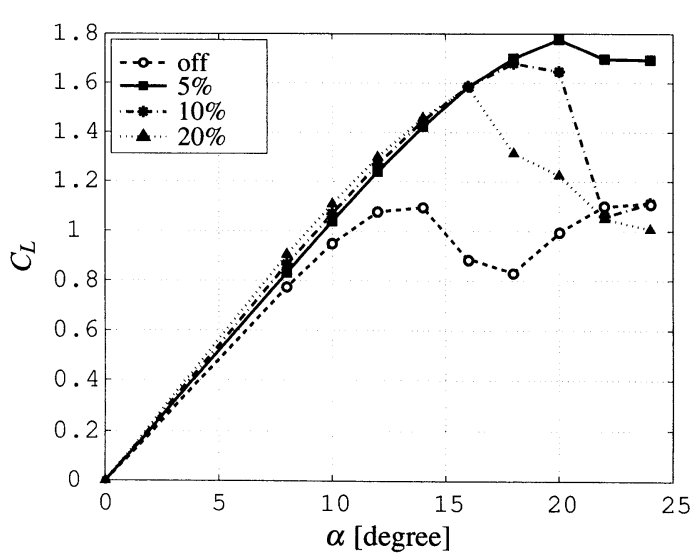

Fig. $6 C_{L}$ vs. angles of attack for each actuator location $\left(D_{c}=50\right)$

がわかる.これと比較すると，プラズマアクチュエー 夕を使用することで，失速特性を大きく改善できてい ることがわかる. 失速角以後に, 揚力係数が上昇して いるものもあるが, それらは迎え角上昇に伴う下面の 圧力上昇が一つの要因として挙げられるが, 本論文の 趣旨から逸れるため詳しい議論牥避ける。位置に関し ては, 前縁近くにプラズマアクチュエータを配置した ときのほうがょり改善できていることがわかる。これ は NACA 0012 翼が前縁から大きくはく離しやすいこ とを考えれば，はく離点が存在する位置近くに配置す るほうが効果を発揮するということができ, 值観的な 予想と一致する。しかしながら，失速の様子としては， 10, 20\%位置の場合と $5 \%$ 位置の場合では少し異なっ ており，5\%位置の場合では，失速後の $C_{L}$ の下がり方 が他の場合に比べて緩やかとなっている.

次に流れ場から考察する. 図7( a ) ( c ) に, それ ぞれの配置における, 迎え角 $18^{\circ}$ での速度の翼弦方向 成分を一様流速で無次元化したものおよび, 流線を表 示する.これらと図 6 を見ると, アクチュエータを使 用しない場合迎え角 $15^{\circ}$ ですでに失速していたもの

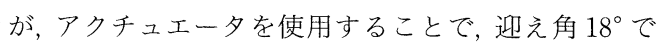
も流れの付着を維持できていることがわかる.しか し, 前縁より遠い $20 \%$ 翼弦位置に配置したときには， この迎え角では, 前縁から大きくはく離している.

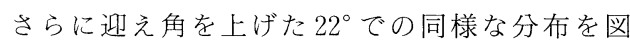
$8(\mathrm{a})$ ，（b)に示す。ただし，20\%翼弦位置に配置した 場合の分布は，迎え角 $18^{\circ}$ の場合 $[$ 図 $7(\mathrm{c})]$ とほぼ 同様であるので省略する。この迎え角では, 10\%翼弦 位置に配置したとき, 流れは前縁から大きくはく離し ており [図 $8(\mathrm{~b})]$, 図 6 より予想できるとおりであ る。図 $8(\mathrm{a})$ を見ると，5\%翼弦位置に配置した場合で 


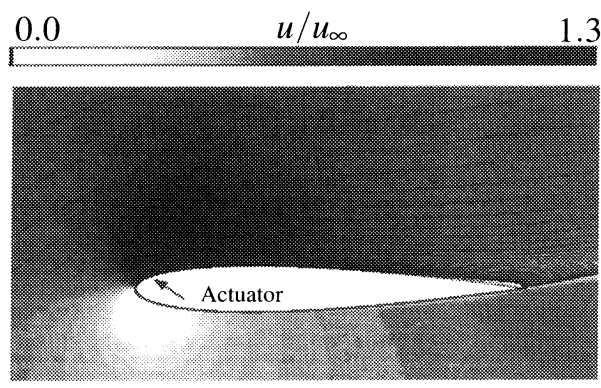

(a) $5 \%$ chord

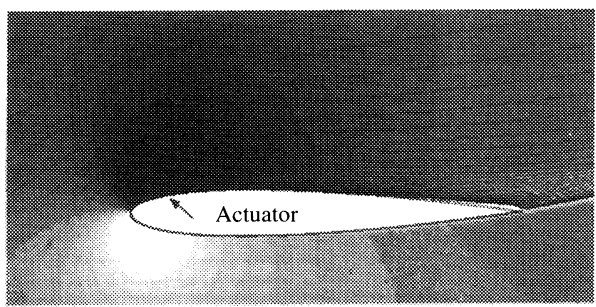

(b) $10 \%$ chord

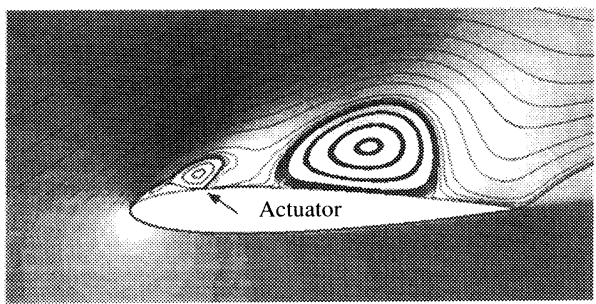

(c) $20 \%$ chord

Fig. 7 Stream-lines and $u$-velocity contours (chordwise component of the velocity vector $u_{i}$ ) at 18 degrees of angle of attack. Arrows point out actuator locations

は後縁から流れがはく離し始めていることがわかる. これが, 図 6 において，5\%翼弦位置にアクチュエータ を配置した場合に $C_{L}$ の下がり方が滑らかであった理 由であると考えられる。前縁からはく離しようとする 流れをアクチュエータにより迎えることで, 流れ場は 後縁にかけて大きな圧力回復を強いられる．その結果 大きな逆圧力こう配が生じ，アクチュエータの影響が 及びにくい後縁においてはく離を起こすと考えられ る.

このように，単数のアクチュエータでは，はく離点 近くに配置すると効率よくはく離の制御が行えるが, さらに迎え角を上げると別の位置からのはく離が生じ てしまい，そのはく離を制御できないことがわかる。 単数のアクチュエータでは，それが限界であり，さら

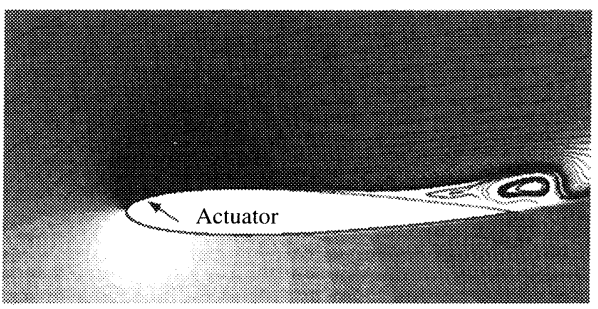

(a) $5 \%$ chord

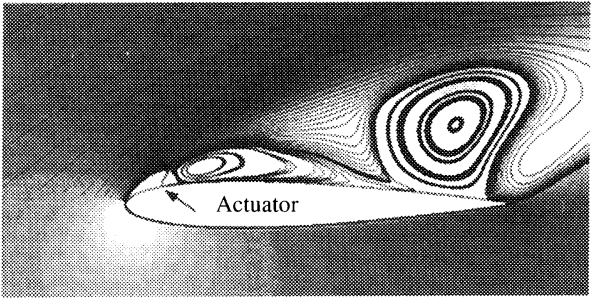

(b) $10 \%$ chord

Fig. 8 Stream-lines and $u$-velocity contours (chordwise component of the velocity vector $u_{i}$ ) at 22 degrees of angles of attack. Arrows point out actuator locations

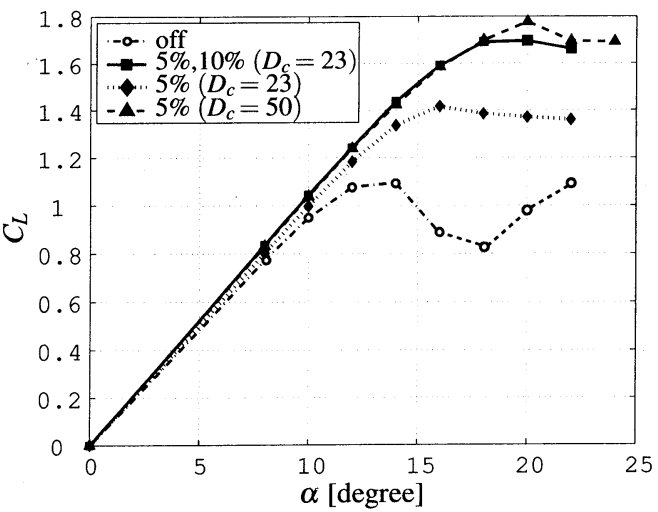

Fig. $9 C_{L}$ vs. angles of attack for actuator locations

に翼の性能を上げるには, 異なる位置にいくつかのア クチュエータを配置することが必要となると考えられ る、また，それらのうち迎え角等の気流条件に応じて 動的にその一部を利用することで，より有効な動的制 御が期待できる. $4 \cdot 2$ 節では入力電圧低減を目的とし， 二つのアクチュエータを配置した場合を示す。

$4 \cdot 2$ 二つのアクチュエータを用いた場合 ここ では，二つのアクチュエータを翼上面に配置した場合 を考察する，翼上面に前縁より $5 \%$ および 10\%翼弦位 置両方にアクチュエータを配置する，このときの揚力 係数 $C_{L}$ の迎え角 $\alpha$ による変化を図 9 に示す.

$D_{c}=23$ で上記の二つの使用した場合と，5\%位置に 


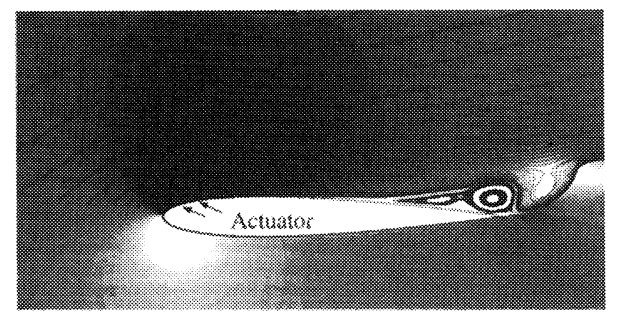

Fig. 10 Stream-lines and $u$-velocity contours (chordwise component of the velocity vector $u_{i}$ ) at 22 degrees of angles of attack with $5 \%$ and $10 \%$ actuators $\left(D_{C}=23\right)$. Arrows point out actuator locations

単数配置し， $D_{c}$ を 23,50 で使用した場合の結果を比 較している. 同じ $D_{c}$ 值では, 複数のアクチュエータ を使用したほうが，より高い迎え角まではく離を抑制 できることは予想通りである，単数のアクチュエータ を $D_{c}=50$ で使用したときと複数使用の場合を比較す ると，ほとんど同じ特性をしている。迎え角 $22^{\circ}$ での 翼弦方向速度成分分布は図 10 のようになっており, 図 8(a)との比較により流れ場においてもほぼ同様で あることがわかる. $D_{c}$ が, 入力電圧の指標であった ことを思い出せば, 二つのアクチュエータを用いるこ とで, 単数の場合よりも低い入力電圧で同様な効果を 得ることができる可能性を示唆している. ある程度以 上の入力電圧で誘起速度が漸近的になるという報告 ${ }^{(7)}$ を考えると, 複数のアクチュエータの利用が有効であ ることがわかる。しかしながら, 後縁からのはく離を 生じてしまうことも同様に現れているため, 別の対策 を施す必要も生ずる。

\section{5. おわりに}

本論文では, NACA 0012 翼に対して,プラズマア クチュエータを用いたはく離制御におけるアクチュエ ータの配置について, 数值シミュレーションを用いて 考察した. 単数のアクチュエータを使用するときは, はく離点に近いアクチュエータが最も効果を発揮する ことが確認できた。 また，単数のアクチュエータでは， いくらはく離点の近傍に配置したとしても, より高迎 え角では別の部分から流れははく離し，そのはく離に は追従できないことも示された。

二つアクチュエータを配置することは，単数の場合 に対して低い入力電圧で同様な制御が行え, 適切な配 置を施すことで，より有効な流れ制御が行える可能性 が示された。これらより, 後縁も含めた複数のアクチ ュエータを翼面上に配置することは, 流れ場に応じて
それらの入出力を個別に動的に制御することで，より 高度な動的流れ制御の可能性をもつことが期待でき る.

\section{文献}

(1) Schaeffler, N.W. et al., "Overview of Active Flow Control Actuator Development at NASA Langley Research Center", AIAA Paper 2002-3159 (2002).

(2) Corke, T.C. and Post, M. L., "Overview of Plasma Flow Control: Concepts, Optimization, and Applications", AIAA Paper 2005-563 (2005).

(3) Van Ness II, D. K. et. al., "Turbine Tip Clearance Flow Control using Plasma Actuators", AIAA Paper 2006-21 (2006).

(4) Enloe, C. L. et al., "Frequency Effects on the Efficiency of the Aerodynamic Plasma Actuator", AIAA Paper 2006-165 (2006).

(5) Orlov, D. M. et. al., "Electric Circuit Model for Aerodynamic Plasma Actuator", AIAA Paper 2006-1206 (2006).

(6) Patel, M. P. et. al., "Autonomous Sensing and Control of Wing Stall Using a Smart Plasma Slat", AIAA Paper 2006-1207 (2006).

(7) Roth, J. R. and Dai, X., "Optimazation of the Aerodynamic Plasma Actuator as an Electrohydrodynamic (EHD) Electrical Device", AIAA Paper 2006-1203 (2006).

(8) Suzen, Y. B. and Huang, P. G., "Simulations of Flow Separation Contorl using Plasma Actuator", AIAA Paper 2006-877 (2006).

(9) Visbal, M. R. and Gaitonde, D. V., "Control of Transitional and Turbulent Flows Using Plasma-Based Actuators", AIAA Paper 2006-3230 (2006).

(10) Jukes, T. N. et. al., "Turbulent Drag Reduction by Surface Plasma through Spanwise Flow Oscillation", AIAA Paper 2006-3693 (2006).

(11) Saminy, M. et. al., "Flow and Noise Control in High Speed and High Reynolds Number Jets Using Plasma Actuators", AIAA Paper 2006-2846 (2006).

(12) Thomas, F. O. et. al., "Plasma Actuators for Landing Gear Noise Reduction”, AIAA Paper 2005-3010 (2005).

(13) Kawai, S. and Fujii, K., "Analysis and Prediction of Thin-Airfoil Stall Phenomena with Hybrid Turbulence Methodology", AIAA Journal, Vol.43, No. 5 (2005), pp. 1265-1275

(14) Baldwin, B. and Lomax, H., "Thin Layer Approximation and Algebraic Model for Separated Turbulent Flows", AIAA Paper 1978-257 (1978).

(15) Shima, E. and Jounouchi, T., "Role of CFD in Aeronautical Engineering (No.14)-AUSM Type Upwind Schemes-", 14th NAL Symposium on Aircraft Computational Aerodynamics, (1997).

(16) Van Leer, B., "Toward the Ultimate Conservative Difference Scheme. 4, A New Approach to Numerical Convection", Journal of Computational Physics, Vol. 23 (1977).

(17) Fujii, K., "Efficiency Improvement of Unified Implicit Relaxation/Time Integration Algorithms", AIAA Journal, Vol. 37, No. 1 (1999), pp. 125-128.

(18) Fujii, K. and Obayashi, S., "Practical Applications of New LU-ADI Scheme for the Three-Dimensional Navier-Stokes Computation of Transonic Viscous Flow", AIAA Paper 1986-513 (1986). 
(19) Font, G. I. and Morgan, W. L., "Plasma Discharges in Atmospheric Pressure Oxygen for Boundary Layer Separation Control", AIAA Paper 2005-4632 (2005).

(20) Singh, K. P. et. al., "Modeling of Dielectric Barrier Discharge Plasma Actuator with Atmospheric Air
Chemisty", AIAA Paper 2006-3381 (2006).

(21) Shyy, W. et al., "Modeling of glow discharge-induced fluid dynamics", Journal of Applied Physics, Vol.92, No. 11 (2002), pp. 6434-6443. 